\title{
The Strategy of Small and Medium Enterprises in the Implementation of Green Human Resource Management in Bandung Regency
}

\author{
Ivan Gumilar Sambas Putra', Andhika Ligar Hardhika², Neneng Susanti ${ }^{3}$ \\ ${ }^{1,2,3}$ Faculty of Economis and Business Management, Universitas Widyatama, Indonesia \\ ivan.gumilar@widyatama.ac.id, andhika.ligar@widyatama.ac.id,neneng.susanti@widyatama.ac.id
}

\begin{abstract}
Workers as the main actors of SMEs need to understand environmental management as an aspect in order to increase business productivity. Green Human Resource Management (Green HRM) is a tool that can be used to manage the SME workforce by involving environmental aspects. The purpose of this study is to determine the priority of Green HRM criteria for SMEs in Bandung Regency. It is hoped that by producing Green HRM criteria for SMEs and the level of importance for each criterion, strategic steps can be formulated in optimizing Green HRM for SMEs in Bandung Regency. In this research, the research method used is descriptive qualitative method. The method of data collection is done by using a questionnaire with a scale of comparison, interviews and field observations. The data analysis technique was performed using analytical hierarchy process (AHP). The results showed that the implementation of green HRM in SMEs was carried out in an organized manner starting from the recruitment process, selection, training and development, performance evaluation, awards, job descriptions of the workforce and workforce management based on the green concept. Among these processes, the training and development process has the highest weight, which shows it is the most important process in implementing green HRM in SMEs. job description of manpower and manpower management which is based on the green concept. Among these processes, the training and development process has the highest weight which shows it is the most important process in implementing green HRM in SMEs. job description of manpower and workforce management based on the green concept. Among these processes, the training and development process has the highest weight which shows it is the most important process in implementing green HRM in SMEs.
\end{abstract}

Keywords

UMM Green; Human Resource Management (IPM); ATP, training and development

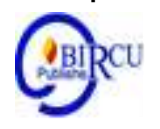

\section{Introduction}

In recent years, SMEs are a business sector that plays a role and plays a role in the economy both nationally and globally. In the national economy, SMEs have a very large share. UKM is a strong fortress of an economy in facing various kinds of dynamics that occur in the economy. UKM also shows a vital role in terms of quantity and absorption of labor. Based on data from the Ministry of Cooperatives and Small and Medium Enterprises of the Republic of Indonesia in 2017, it shows that $99.99 \%$ (percent) of business units in Indonesia are Small and Medium Enterprises (SMEs) and 0.01\% (percent) are large enterprises, absorption rate workforce reached $97.02 \%$ (percent), and had a contribution to the Gross Domestic Product (GDP) of $60.00 \%$ (percent). 
Based on these data, SMEs are an economic sector that plays an important role in economic growth and employment in Indonesia. Environmental issues are an important factor for the development of SMEs. SMEs can contribute to environmental problems, such as pollution of gas, liquid, and solid waste, so that UKM managers are obliged to participate in solving these environmental problems (Fiscal Policy, 2012). Therefore, to ensure business sustainability, it is necessary to introduce environmental and social aspects in the business process (Kondoh, 2014). Environmental management in the operational process of SMEs has a positive effect on the sustainability of SMEs in the short and long term (Zeng, 2011). Workers as the main actors of SMEs need to understand environmental management as an aspect in order to increase business productivity. Green Human Resource Management (Green HRM) is a tool that can be used to manage the SME workforce by involving environmental aspects.

The Central Bureau of Statistics (BPS) defines SMEs as companies that have a workforce of between 5 and 19 employees (BPS, 1997). If a company has less than 5 employees, it can be called a home industry. Kurilof in Pasaribu (2005) states that to be able to guarantee the survival of SMEs, UKM players have four balanced abilities, namely: (1) Technical competence, which is having competence in the field of design (know-how) in accordance with the business that is will be selected. (2) Marketing competence, namely having competence in finding suitable markets, identifying customers and maintaining the survival of the company. (3) Financial competence, namely having competence in finance, managing purchases, sales, bookkeeping, and profit / loss calculations.

When viewed from the perspective of development potential, SMEs can become an economic sector that has the potential to be developed into the international realm. There are several types of SME products that are suitable for use as superior export products, but in their development, there are obstacles in reaching the export market, including domestic policies and a lack of information on various needs in the export market so policies and strategies are needed to overcome this (Cardoza et al., 2016). Currently labor-intensive is one of the strong characteristics of SMEs, as for the ability to use technology that is simple, easy to understand and able to become a place for people to work (Anggraeni et al., 2013). The high level of use / use of labor in SMEs can make the role of labor very important for SMEs. Workers are no longer workers but have turned into business capital for SMEs (human capital). In addition, the author's research results indicate a positive relationship between labor and SME productivity but the role of labor in increasing SME productivity is still low (Astuti et al., 2013). Therefore, it is necessary to increase the role of the SME workforce in order to increase the productivity of SMEs.

The existence of several environmental issues is a very important factor for the development of SMEs. Companies, both on the micro, small and medium and large scale cause environmental problems, such as the presence of gas, liquid and solid waste pollution, so companies are obliged to participate in solving environmental problems (Agan et al., 2013). Therefore, to ensure business sustainability, it is necessary to introduce environmental and social aspects in the business framework (Kondoh et al., 2014). Environmental management in the business operational process (UKM) has a positive influence on the sustainability of SMEs in the short and long term (Zeng et al., 2011).

Workers as the main actors of SMEs need to understand environmental management as an aspect in order to increase business productivity. Green human resource management (Green HRM) is a tool that can be used to manage the SME workforce by involving environmental aspects. Currently, the management of the SME workforce does not involve environmental aspects, it still focuses on workforce competence (Ardiana and Subaedi, 
2010), SME performance measurement (Lin and Lin, 2016) and innovation in SMEs (Gu et al., 2015). Green HRM is a workforce management system that is implemented to reduce negative impacts on the environment or increase positive environmental impacts on SME performance in a sustainable manner (Arulrajah et al., 2015). Green human resource management is the development of human resource management (HRM) which in Indonesia is known as human resource management, namely: a policy and practice that is needed by someone who carries out the aspects of people or recruitment, screening, training, reward, and assessment (Desler in Tiffani, 2013). HRM is the most important aspect in business management, through an innovative approach so as to improve the economy, technology, socio-culture and environment of the company (Cech et al., 2016). More than that, the demands of the economy, globalization, domestic diversity and technology have encouraged companies to make various management developments in the field of corporate human resources (Stone and Deadrick, 2015). But, on the other hand.

The results of the study (Wahyuni et al., 2015) show that the human resource aspect has a lower level of importance when compared to technology (technoware) in the process of technology adoption in SMEs. One form of development in the HRM field is by adding an environmental element, hereinafter known as green HRM, which facilitates employee involvement in environmental management, manifested in a joint commitment to change actions in order to support the organization in its efforts to implement environmental management (protection) ( Pinzone et al., 2016). Green HRM is focused on systemic planning related to human resource management practices that are in accordance with organizational goals in environmental management (Millar et al., 2016). The implementation of green HRM is one form of effort to increase productivity and the commitment of companies (SMEs) in maintaining environmental sustainability. Several forms of green HRM implementation in companies are carried out through performance management, training, development, and learning, compensation and benefits and organizational culture (Jackson et al., 2011). More than that, the implementation of green HRM requires a strong commitment from management at the top level, through a form of comprehensive planning as a guideline by employees at the operational level (Fayyazi et al., 2015). With this, the implementation of green HRM will provide several benefits for the company, including: (1) improvement in the employee retention process, (2) improving the company's name in the general public, (3) getting better employees.

Although research on halal in the pharmaceutical world is starting to get attention, its existence is not yet maximized as can be understood based on the above chart. This condition is what motivates the authors to conduct this research with the title "Dynamics of Application of Halal Certification in Medicinal Products (Comparative Study of Islamic Law and Positive Law)".

\section{Review of Literature}

\subsection{Green HRM in Human Resources Practices}

To be able to implement the Green HRM concept in the organization, each organization can incorporate environmentally friendly concepts into the HRM functions. Opatha \& Anton (2014) suggest that traditionally there are 18 HRM functions including job design, job analysis, human resource planning, recruitment, selection, recruitment, induction, performance evaluation, training and development, career management, compensation management, incentive management, welfare management, employee movement management, discipline management, health and safety management, labor relations management. Creating Green HRM practices can be done by involving the inclusion of 
policies, procedures and practices that ensure employees behave in an environmentally friendly manner and employees have good performance. Meanwhile Cherian \& Jelly (2012).

Implementation of environmentally friendly behavior in training is carried out to provide appropriate knowledge and skills about greening or friendly behavior for each employee through training programs specifically designed for reforestation (perron et a12006, Daily et a12007, Unnikrishnan \& Hadge 2007, Sarkis et al. 2010, Opatha \& Anton 2014). In addition, to conduct a tracking needs analysis to identify environmentally friendly training needs for employees. Implementation in Performance Evaluations, to evaluate work performance of employees in accordance with the criteria for environmentally friendly behavior (Mandip 2012).

Human resource development is an effort to develop the quality or ability of human resources through the process of planning education, training and management of personnel or employees to achieve an optimal result (Notoatmodjo in sulasmi, 2020). The development of human resources through the cultivation of achievement motivation is one of the contributions in improving the quality of human resources. (Werdhiastutie, 2020)

Human resource development is an effort to develop the quality or ability of human resources through the process of planning education, training and management of personnel or employees to achieve an optimal result (Notoatmodjo in Sulasmi, 2020). Human resources as labor or employees play an important role in improving productivity and achievement of predetermined objectives. Efforts to mobilize labor are an important task for agencies. In this case the agency should be able to do coaching on employees so that they want to perform work activities effectively and efficiently. (Ningsih, 2018).

\subsection{Triple Bottom Line Theory}

The triple bottom line theory gives that understanding if a company wants to maintain its survival, the company must pay attention to "3P". In addition to pursuing profit, companies must also pay attention to and be involved in fulfilling the welfare of the community (people) and contribute actively to preserving the environment (planet) (Wibisono 2007).

a. Profit; Profit is the main and most important goal in every business activity. It is not surprising that the main focus of all activities within the company is to pursue profit and to increase the share price as high as possible. Because this is the most essential form of economic responsibility to the sabam holder. Activities that can be taken to boost profits include increasing productivity and carrying out cost efficiency. Increased productivity can be obtained by improving work management from simplifying processes, reducing inefficient activities, saving process and service time. Meanwhile, cost efficiency can be achieved if the company uses materials as economically as possible and cuts costs as low as possible.

b. People (Community Stakeholders); People or the community are very important stakeholders for the company, because community support is very necessary for the existence, survival and development of the company. Therefore, companies need to be committed to striving to provide maximum benefits to the community. It is also necessary to realize that the company's operations have the potential to have an impact on the community. Therefore, the company needs to carry out various activities that can meet community needs.

c. Planet (Environment); Planet or the environment is something that is related to all areas of human life, because all activities carried out by humans as living things are always related to the environment, for example drinking water, inhaled air and all equipment used, all of which come from the environment. However, the majority of humans still don't care about the surrounding environment. This is because there is no direct benefit that can be taken in it. 


\section{Research Methods}

The research object used is SME types of processed food and beverages in the Bandung Regency area, with the research sample being SMEs with a minimum workforce of 5 people. The data collection method used was interviews conducted to obtain information. Interviews will be conducted with UKM managers, academics and local governments who hold policies related to SME development. Focus Group Discussion (FGD) which is conducted as a discussion media between researchers, UKM players, academics, and local government which aims to explore opinions about the suitability of the research result model. The questionnaire is a tool to determine the level of importance of each criterion in green HRM. The respondent respondents are experts who have competence in implementing green HRM, among others, academics who understand the green HRM concept. This study uses data processing techniques using AHP (Analytical Hierarchy Process) method. AHP is a decisionmaking method based on the weight of each criterion developed by Thomas L. Saaty in 1988 (Susihono, 2013). According to (Darmanto et al., 2014) AHP is carried out first by compiling a hierarchy of several complex / multi-factor problems so that problems will appear to be more structured and systematic in several fields of study. AHP has been widely used, such as determining the priority of technology components by giving weighting (Cahyono and Wahyuni, 2015), and determining the location which is considered as priority determination (Erbiyik et al., 2012).

This study uses data processing techniques using AHP (Analytical Hierarchy Process) method. AHP is a decision-making method based on the weight of each criterion developed by Thomas L. Saaty in 1988 (Susihono, 2013). According to (Darmanto et al., 2014) AHP is carried out first by compiling a hierarchy of several complex / multi-factor problems so that problems will appear to be more structured and systematic in several fields of study. AHP has been widely used, such as determining the priority of technology components by giving weighting (Cahyono and Wahyuni, 2015), and determining the location which is considered as priority determination (Erbiyik et al., 2012). AHP is a decision making method that is based on the weight of each criterion developed by Thomas L. Saaty in 1988 (Susihono, 2013). According to (Darmanto et al., 2014) AHP is carried out first by compiling a hierarchy of several complex / multi-factor problems so that problems will appear to be more structured and systematic in several fields of study. AHP has been widely used, such as determining the priority of technology components by giving weighting (Cahyono and Wahyuni, 2015), and determining the location which is considered as priority determination (Erbiyik et al., 2012). AHP is a decision making method that is based on the weight of each criterion developed by Thomas L. Saaty in 1988 (Susihono, 2013).

According to (Darmanto et al., 2014) AHP is carried out first by compiling a hierarchy of several complex / multi-factor problems so that problems will be seen to be more structured and systematic in several fields of study. AHP has been widely used, such as determining the priority of technology components by giving weighting (Cahyono and Wahyuni, 2015), and determining the location which is considered as priority determination (Erbiyik et al., 2012). 2014) AHP is carried out first by compiling a hierarchy of several complex / multi-factor problems so that problems will be seen to be more structured and systematic in several fields of study. AHP has been widely used, such as determining the priority of technology components by giving weighting (Cahyono and Wahyuni, 2015), and determining the location which is considered as priority determination (Erbiyik et al., 2012). 2014) AHP is carried out first by compiling a hierarchy of several complex / multi-factor problems so that problems will be seen to be more structured and systematic in several fields of study. AHP has been widely used, such as determining the priority of technology 
components by giving weighting (Cahyono and Wahyuni, 2015), and determining the location which is considered as priority determination (Erbiyik et al., 2012).

AHP calculation steps begin by formulating the criteria $\mathrm{C}=\{\mathrm{Cj} / \mathrm{j}=1,2, \ldots \mathrm{n}\}$. The scale of comparison (pairwaise comparison) for $n$ criteria arranged in a matrix A (nxn) where aij $(i, j=1,2, \ldots n)$ is the weight of each. Furthermore, each matrix is normalized to find the relative weight, which is called the eigenvactor $(w)$ and is related to the eigenvalue $(\lambda=$ mak) through the following equation:

$$
A_{w}=\lambda_{\max } \cdot \mathrm{W}
$$

The more consistent the answer, the value of 1 mak tends to be closer to $n$. Saaty (1980) has developed a consistency index to measure the consistency of judgment when making comparisons by formulating a consistency index (CI) as:

$$
C l=\frac{\ell_{\operatorname{mik}}-n}{(n-1)}
$$

Index $\mathrm{CI}=0$ reflects "pairwise comparision" of perfectly consistent judgment. Then the CR (Consistency Ratio Index) index is developed which is defined as the CI ratio for a particular judgment with the CI of "random judgment". It's time has suggested that the CR should be below $10 \%(0.1)$ to show that the "value judgment" given is acceptable, and otherwise requires revision or review.

\section{Result and Discussion}

Retrieval of data obtained from the results of the questionnaire which is measured based on a comparison scale, according to (Jabbaur \& Jabbaur, 2016) for the formulation of criteria that will be used in developing a green HRM implementation strategy based on several aspects including aspects of employee recruitment, performance evaluation, training and employee performance development. Evaluation, award, design and job description analysis containing green elements with the following conditions:

\begin{tabular}{|c|c|c|}
\hline Intensity of Interest & Definition & Information \\
\hline 1 & Same Interests & Two activities contribute equally to a goal \\
\hline 2 & $\begin{array}{l}\text { One is more } \\
\text { important than the } \\
\text { other }\end{array}$ & $\begin{array}{l}\text { One activity is more important than other } \\
\text { activities, but the advantages are less } \\
\text { convincing or not significant }\end{array}$ \\
\hline 5 & $\begin{array}{l}\text { Has essential } \\
\text { importance }\end{array}$ & $\begin{array}{l}\text { There is good evidence and logical criteria that } \\
\text { one activity is more important than another }\end{array}$ \\
\hline 7 & $\begin{array}{l}\text { Importance is } \\
\text { highlighted }\end{array}$ & $\begin{array}{l}\text { One activity is more important than other } \\
\text { activities if it can be proven conclusively }\end{array}$ \\
\hline 9 & $\begin{array}{l}\text { Has absolute } \\
\text { importance }\end{array}$ & $\begin{array}{l}\text { An activity expressly has the highest } \\
\text { importance }\end{array}$ \\
\hline $2,4,6,8$ & $\begin{array}{l}\text { The value between } \\
\text { two interests }\end{array}$ & $\begin{array}{l}\text { An agreement is needed to determine the level } \\
\text { of importance }\end{array}$ \\
\hline
\end{tabular}

Table 1. Scale of comparison

Source: ESCAP (1988b: 56) 
Table 2. Criteria for green HRM

\begin{tabular}{|c|c|}
\hline Criteria & Sub Criteria \\
\hline Recruitment (R) & $\begin{array}{l}\text { 1. Incorporate environmental elements into the company's recruitment } \\
\text { strategy (R1) } \\
\text { 2. Include environmental elements as one of the recruitment criteria (R2) } \\
\text { 3. Communicating company policies / commitments to environmental } \\
\text { sustainability during the recruitment process (R3) } \\
\text { 4. Include elements of knowledge about the environment in job } \\
\text { advertisements (R4) } \\
\text { 5. Informing that the company will recruit prospective employees who } \\
\text { have environmental management competencies (R5) }\end{array}$ \\
\hline Selection (S1) & $\begin{array}{l}\text { 1. Consider candidates who have an interest and concern for the } \\
\text { environment (S1) } \\
\text { 2. Asking questions related to environmental management during } \\
\text { interviews with prospective employees (S2) } \\
\text { 3. Having prospective employees who are aware of environmental } \\
\text { management (S3) } \\
\text { 4. Having prospective employees who have personally carried out } \\
\text { environmental management (S4) }\end{array}$ \\
\hline $\begin{array}{l}\text { Training and } \\
\text { development (PP) }\end{array}$ & $\begin{array}{l}\text { 1. Developing employee skills and knowledge about environmental } \\
\text { management through training (PP1) } \\
\text { 2. Provide best practices on environmentally friendly activities (PP2) } \\
\text { 3. Provide training to remind environmental awareness in each } \\
\text { workforce (department of work) (PP3) } \\
\text { 4. Providing environmental education programs for employees (PP4) } \\
\text { 5. Provide training to employees so that they can turn the workspace } \\
\text { into a green space (PP5) } \\
\text { 6. Applying job rotation to train managers in understanding the } \\
\text { environment (PP6) } \\
\text { 7. Provide special training for reforestation activities for employees } \\
\text { (PP7) } \\
\text { 8. Conduct a needs analysis to define the types of training required for } \\
\text { reforestation (PP8) } \\
\text { 9. Conduct analysis and identification of training needs that can } \\
\text { increase employee awareness of the environment (PP9) } \\
\text { 10. Provide opportunities for everyone in the company to be trained } \\
\text { in environmental management aspects (PP10) }\end{array}$ \\
\hline $\begin{array}{l}\text { Performance } \\
\text { evaluation (PE) }\end{array}$ & $\begin{array}{l}\text { 1. Establish an environmental management information system (EMIS) } \\
\text { and environmental audit (PE1) } \\
\text { 2. Integrate the goals and targets of environmental management in the } \\
\text { company performance evaluation system (PE2) } \\
\text { 3. Adhere to overall environmental performance standards (PE3) } \\
\text { 4. Integrate elements of environmental performance into employee } \\
\text { performance appraisals (PE4) } \\
\text { 5. Setting goals, targets and environmental responsibilities (PE5) } \\
\text { 6. Provide feedback to employees about environmental performance to } \\
\text { improve employee performance (PE6) } \\
\text { 7. Conduct evaluation / measurement of environmental performance } \\
\text { for each employee (PE7) }\end{array}$ \\
\hline
\end{tabular}




\begin{tabular}{|l|l|}
\hline Appreciation (P) & $\begin{array}{l}\text { 1. Appreciate employee environmental performance (good, not good or } \\
\text { very good) (P1) }\end{array}$ \\
& $\begin{array}{l}\text { 2. Giving financial and financial awards to employees who have good } \\
\text { environmental performance (P2) }\end{array}$ \\
$\begin{array}{l}\text { 3. Communicate or socialize environmental excellence generated by } \\
\text { employees (P3) }\end{array}$ \\
$\begin{array}{l}\text { 4. Provide incentives for employees who behave in an environmentally } \\
\text { friendly manner }\end{array}$
\end{tabular}

Source: Research by 2020

The questionnaire was distributed to two people who are experts in green HRM, with the criteria and sub criteria shown in Table 2 and the calculations using the AHP steps are shown in Table 3.

Table 3. Weighting results among green HRM sub criteria

\begin{tabular}{|c|c|c|}
\hline Criteria & Sub Criteria & Prioritv Weights \\
\hline $\mathrm{R}$ & $\begin{array}{l}\text { R1 } \\
\text { R2 } \\
\text { R3 } \\
\text { R4 } \\
\text { R5 }\end{array}$ & $\begin{array}{c}0,19 \\
0,35 \\
0,38^{*} \\
0,04 \\
0,04\end{array}$ \\
\hline $\mathrm{S}$ & $\begin{array}{l}\text { S1 } \\
\text { S2 } \\
\text { S3 } \\
\text { S4 }\end{array}$ & $\begin{array}{c}0,30 \\
0,62^{*} \\
0,04 \\
0,04\end{array}$ \\
\hline PP & $\begin{array}{l}\text { PP1 } \\
\text { PP2 } \\
\text { PP3 } \\
\text { PP4 } \\
\text { PP5 } \\
\text { PP6 } \\
\text { PP7 } \\
\text { PP8 } \\
\text { PP9 } \\
\text { PP10 }\end{array}$ & $\begin{array}{c}0,16^{*} \\
0,16^{*} \\
0,14 \\
0,05 \\
0,09 \\
0,07 \\
0,06 \\
0,09 \\
0,07 \\
0,07\end{array}$ \\
\hline PE & $\begin{array}{l}\text { PE1 } \\
\text { PE2 } \\
\text { PE3 } \\
\text { PE4 } \\
\text { PE5 } \\
\text { PE6 } \\
\text { PE7 }\end{array}$ & $\begin{array}{c}0,14 \\
0,05 \\
0,38^{*} \\
0,06 \\
0,21 \\
0,08 \\
0,08\end{array}$ \\
\hline $\mathrm{P}$ & $\begin{array}{l}\text { P1 } \\
\text { P2 } \\
\text { P3 } \\
\text { P4 }\end{array}$ & $\begin{array}{c}0,11 \\
0,47^{*} \\
0,25 \\
0,17\end{array}$ \\
\hline $\mathrm{G}$ & $\begin{array}{l}\text { G1 } \\
\text { G2 } \\
\text { G3 } \\
\text { G4 }\end{array}$ & $\begin{array}{c}0,19 \\
0,63^{*} \\
0,13 \\
0,05\end{array}$ \\
\hline GH & $\begin{array}{l}\text { GH1 } \\
\mathrm{GH} 2\end{array}$ & $\begin{array}{l}0,5^{*} \\
0,5^{*}\end{array}$ \\
\hline
\end{tabular}


Table 4. Weighting results between criteria

\begin{tabular}{|c|c|}
\hline Criteria & Priority Weights \\
\hline R & 0,06 \\
\hline S & 0,12 \\
\hline PP & $0,26^{*}$ \\
\hline PE & 0,24 \\
\hline P & 0,04 \\
\hline G & 0,14 \\
\hline GH & 0,14 \\
\hline
\end{tabular}

* the highest weight on each criterion

In Table 3 and Table 4, it can be seen that for the sub-criteria priority weights, there is the highest weight among other sub-criteria. The highest weight on these sub criteria is more important than other sub criteria.

1. Recruitment criteria, the highest weight is in sub criteria R3, which is to communicate the company's policy / commitment to environmental sustainability during the recruitment process.

2. The selection criteria, the highest weight is in the S2 sub-criteria, namely asking questions related to environmental management during interviews with prospective employees.

3. Training and development criteria, the highest weight is in the sub-criteria to develop employee skills and knowledge about environmental management through training (PP1) and providing best practices on environmentally friendly activities (PP2).

4. Performance evaluation criteria, the highest weight is in the sub-criteria to control the overall environmental performance standard.

5. The award criteria, the highest weight is in the sub-criteria of giving financial and nonfinancial awards to employees who have good environmental performance.

6. Green job criteria for design and analysis, the highest weight is on the sub-criteria to form a cross-departmental team to manage the company's environmental problems.

7. Green HRM criteria consist of 2 sub-criteria which have the same weight, namely including the number of employees and types of employees to implement the company's environmental management activity program and formulate a strategy to manage the environment, for example through environmental audits by experts

To be able to see a comparison between the criteria, it can be seen in Table 4, it can be concluded that from the 7 green HRM criteria that have been determined, the highest weight is on the training and development criteria. The priority level is indicated by the highest weight in the implementation of green HRM. The process of implementing green HRM in SMEs can be formulated by focusing on the highest value in each criterion. To be able to develop an implementation strategy, it is used on these priorities. In this stage, the strategy is formulated based on the green HRM criteria, namely:

1. Recruitment strategy: more focused on the operational process, where SMEs are expected to formulate a policy / commitment with the aim that these SMEs will implement the green HRM concept. In the policy / commitment, it is continued by observing the existence of several green concept considerations in the recruitment process of prospective workers.

2. Selection strategy: in the selection process as well as a decision making process in recruitment, it is expected that there will be a level of understanding of the green concept.

3. Strategies on training and development, this strategy is more directed by including in some of the training needed and conducting comparative studies in green HRM. This strategy aims to foster a positive impact on green HRM implementation on business sustainability. 
4. The performance evaluation strategy is carried out by incorporating green elements in the SME performance evaluation process. The award strategy is implemented by designing awards in the form of finance for SME workers who have provided innovations in managing the business environment. The green job design strategy and analysis are carried out by including the green element in each job description of each employee. The green HRM strategy is implemented by considering the large number of employees in determining the form of activities that lead to the implementation of green HRM.

The strategies that have been described can be used as concrete strategic steps for SMEs in implementing the green concept in their business.

Based on the results of field observations, it appears that until now the level of understanding of SMEs in implementing the green HRM concept needs to be improved, although most SMEs have made various efforts in environmental management, for example by processing solid and liquid waste, conducting greening in locations around the business, but the process is carried out in the middle of the operational process. This means that the green concept has not been carried out in an integrated manner with the workforce management process starting from recruitment.

\section{Conclusion}

The conclusion in this study shows that SMEs must be able to implement green HRM. This is supported by the role of SMEs which are very important for the development of the country's economy and the characteristics of SMEs that are labor intensive. The implementation of green HRM in SMEs is carried out in an organized manner starting from the recruitment process, selection, training and development, performance evaluation, awards, job descriptions of the workforce and workforce management based on the green concept. The process of implementing green HRM is necessary start with there is a policy / commitment the strong one from owner UKM to implement the concept.

In this study, the authors provide suggestions for further researchers who are expected to know the impact resulting from the implementation of green HRM on company performance to motivate SMEs in implementing the concept.

\section{References}

Agan, Y., and Acar MF Borodin A. (2013). Drivers of environmental processes and their impact on performance: a study of Turkish SMEs, Journal Of Cleaner Production 51, 23-33.

Anggraeni FD and Hardjanto I. Hayat A. (2010). Development of Micro, Small and Medium Enterprises (UKM) through Facilitation of External Parties and Internal Potentials, Journal of Public Administration (JAP). 6, 1286-1295.

Aridiana. Brahmayanti. Subaedi. (2010). Competency of SME HR and Its Effect on SME Performance in Surabaya, Journal of Management and Entrepreneurship, 12 (1), $42-55$.

Arulrajah AA, Opatha H. Nawaratne NNJ. (2015). Green Human Resource Management Practices: A Review, Sri Lanka Journal of Human Resources Management, 5 (1).

Astuti M. Wahyuni HC Sulistiyowati W., Ciptomulyono U., Kartiningsih PD. (2013). Increasing the Productivity of Small and Medium Enterprises (UKM) based on Content Technology to Support Implementation of MP3EI 2011-2025, National Seminar Procedure Faculty of Economics, Muhammadiyah University Sidoarjo, ISBN: 97860298739-1-7. 
Cahyono DE Wahyuni HC. (2015). Technology Assessment Using Analytical Hierarchy Process and Technometrics in the Production Department. Industrial Engineering Scientific Journal. (14) 2. 122-129.

Cahyono, Y., Purwanto, A., Sukanta, FNA, Fitriaty, HW, Sihotang, M., \& Sugianto, A. (2020). IMPACT OF SERVICE QUALITY, UNIVERSITY IMAGE AND STUDENTS SATISFACTION TOWARDS STUDENTLOYALTY: EVIDENCE FROM INDONESIAN PRIVATE UNIVERSITIES. Journal of Critical Reviews, 7 (19), 3916-3924.

Cardoza G. Fornes G. Farber V. Duarte GR Gutierrez JR. (2016). Barriers and Public Policies Affecting The International Expansion of Latin American SMEs: Evidence from Brazil, Colombia, and Peru. Journal Of Business Research 69, 2030-2039.

Cech M. Yao W. Samolejova A. Li J. Wicher P. (2016). Human Resource management in Chinese manufacturing companies, Perpectives In Science 7, pp 6-9.

Cherian J. Jacob J. (2012). A Study of Green HR Practices and Its Effective Implementation in the Organization: A Review, International Journal Of Business And Management. (7) $21,25-33$.

Darmanto E. Latifah N. Susanti N. (2014). Application of the AHP (Analyic Hierarchy Process) Method to Determine the Quality of Cane Sugar. SIMETRIS Journal. (5) 1. $72-85$.

Erbiyik H. Ozcan Z. Karaboga.K. (2012). Retail store location selection problem with multiple analytical hierarchy process of decision making an application in Turkey. Procedia - Social and Behavioral Sciences (58), pp 1405 - 1414.

Fayyazi M. Shahbazmoradi S. Afshar Z. Shahbazmoradi MR. (2015). Investigating the barriers of the green human resource management implementation in oil industry, Management Science Letters 5, 101-108.

Gu Q. Jiang W. Wang GG. (2016). Effects of external and internal sources on innovation performance in Chinese high-tech SMEs: A resource-based perspective, Journal of Engineering and Management Technology, Vol 40, 76- 86

Gumilar, I., Sunarsi, D. (2020). Comparison of financial performance in banking with high car and low car (Study of banks approved in the Kompas 100 index for the period 2013-2017). International Journal of Psychosocial Rehabilitation. Volume 24 - Issue 7

Jackson S. Renwick DWS Jabbour JCJ Camen MM. (2011). State-of-the-Art and Future Directions for Green Human Resource Management: Introduction to the Special Issue, German Journal Of Research In Human Resource Management 25, 96-116.

Kondoh S. Komoto H. Kishita Y. Fukushige S. (2014). Toward a sustainable business design: a survey, Procedia CIRP 15, 367- 372.

Lin FJ, Lin YH. (2016). The effect of network relationship on the performance of SMEs, Journal Of Business Recearch 69, pp 17801784.

Lukiastuti, Fitri, et.al (2020). The Influence of Entrepreneur's Personal Characteristics on SMES Performance Mediated by Entrepreneurial Orientation. International Journal of Psychosocial Rehabilitation. Volume 24 - Issue 8

Maddinsyah, A., Sunarsi, D., Hermawati, R., Pranoto. (2020). Analysis of location selection effect on the user decision that influences the success of the service business of micro, small and medium enterprise (MSME) in bandung timur region. International Journal of Advanced Science and Technology. Vol. 29 No. 06

Millar JH Sanyal C. Camen MM. (2011). Green human resource management: a comparative qualitative case study of a United States multinational corporation, The International Journal of Human Resource Management, Vol 27, No 2,192-211. 
Ningsi, S. (2018). The Relationship Between Motivation and Worker's Productivity in Civil Registration and Population Department, Asahan Regency, Indonesia. Budapest International Research and Critics Institute-Journal (BIRCI-Journal). P. 148-160

Pasaribu. (2005). Analysis of Competency Improvement of Small Entrepreneurs After Participating in Entrepreneurship Training Held by Swisscontact Medan, Journal of Industrial Engineering Systems. (6) 5. 49-52.

Pinzone M. Guerci M. Lettieri E. Redman T. (2016). Progressing in the change journey towards sustainability in healthcare: the role of 'Green' HRM, Journal Of Cleaner Production 122,201-211.

Santos G. Ballros S. Mendes F. Lopes N. (2013). The Main Beneûts Associated With Health and Safety Management Systems Certiûcation In Portuguese Small and Medium Enterprises Post Quality Management System Certiûcation. Safety Science Journal 51. 29-36.

Stone DL Deadrick DL. (2015). Challenges and opportunities affecting the future of human resource management, Human Resource Management Review 25, pp 139- 145.

Sunarsi, D. (2018). Strategic Human Resource Development \& Characteristics of Support Systems: An Overview. MEA Scientific Journal (Management, Economics, \& Accounting), 2 (3), 178 - 194.

Sunarsi, D. (2020). The Analysis of The Work Environmental and Organizational Cultural Impact on The Performance and Implication of The Work Satisfaction. Scientific Journal of Public Administration Science, 9 (2), 237-246.

Sulasmi,E. (2020). The Development Strategy of Human Resources Management In Children's Social Welfare Institution (LKSA) (Case Study in LKSA AL-Mubaraak Orphanage Bengkulu). Budapest International Research and Critics Institute-Journal (BIRCI-Journal).P. 562-569

Susihono W. (2013). Technology Assessment To Determine Competing Industry Position. Journal of Industrial Engineering. (7) 2, pp 131-138.

Tiffani B. Rustam. (2013). Management Audit to Assess the Effectiveness of the Human Resource Function. FEB Student Scientific Journal, Vol 1 No 1.

Wahyuni CH Hartati V. Astuti M. (2015). Identification of Technology Adoption Level to Improve Product Quality in Tofu Small Industry in Sidoarjo Regency, Satellite Processing, Brawijaya University, Malang.

Werdhiastutie, A. et al. (2020). Achievement Motivation as Antecedents of Quality Improvement of Organizational Human Resources. Budapest International Research and Critics Institute-Journal (BIRCI-Journal). P. 747-752

Wijoyo, H., \& Nyanasuryanadi, P. (2020). ANALYSIS OF THE EFFECTIVENESS OF THE IMPLEMENTATION OF THE SUNDAY SCHOOL EDUCATION CURRICULUM BUDDHA IN THE TIME OF COVID-19. JP3M: Journal of Education, Learning and Community Empowerment, 2 (2), 166-174.

Zeng SX, Meng XH, Zeng RC, Tam CM, Tam WY, Jin T. (2011). How environmental management driving forces affect environmental and economic performance of SMEs: a study in the Northern China district, Journal of Cleaner Production 19, pp 1426- 1437. 